\title{
State Social Work and the Working Class
}


Critical Texts in Social Work and the

Welfare State

General Editor: Peter Leonard

Published

Pete Alcock and Phil Harris

WELFARE LAW AND ORDER: A CRITICAL

INTRODUCTION TO LAW FOR

SOCIAL WORKERS

Steve Bolger, Paul Corrigan, Jan Docking and Nick Frost

TOWARDS SOCIALIST WELFARE WORK:

WORKING IN THE STATE

Paul Corrigan and Peter Leonard

SOCIAL WORK PRACTICE UNDER CAPITALISM :

A MARXIST APPROACH

Norman Ginsburg

CLASS, CAPITAL AND SOCIAL POLICY

Ian Gough

THE POLITICAL ECONOMY OF THE WELFARE STATE

Chris Jones

STATE SOCIAL WORK AND THE WORKING CLASS

Chris Phillipson

CAPITALISM AND THE CONSTRUCTION OF OLD AGE

Forthcoming

Lena Dominelli and Eileen McLeod

FEMINISM AND WELFARE:

SOCIAL ACTION AND SOCIAL WORK

Peter Leonard

PERSONALITY AND IDEOLOGY:

TOWARDS A MATERIALIST UNDERSTANDING

OF THE INDIVIDUAL

Geoffrey Pearson

IDEOLOGICAL CRISIS IN SOCIAL WORK 


\section{State Social Work and the Working Class}

Chris Jones 
(c) Chris Jones 1983

Softcover reprint of the hardcover 1st edition 1983 978-0-333-27160-5

All rights reserved. No part of this publication may be reproduced or transmitted, in any form or by any means, without permission.

First published 1983 by THE MACMILLAN PRESS LTD

London and Basingstoke

Companies and representatives throughout the world

ISBN 978-0-333-27161-2 ISBN 978-1-349-17074-6 (eBook)

DOI 10.1007/978-1-349-17074-6

Typeset in Great Britain by

STYLESET LIMITED - Salisbury · Wiltshire

The paperback edition of this book is sold subject to the condition that it shall not, by way of trade or otherwise, be lent, resold, hired out, or otherwise circulated without the publisher's prior consent in any form of binding or cover other than that in which it is published and without a similar condition including this condition being imposed on the subsequent purchaser. 


\section{Contents}

Acknowledgements

List of Abbreviations

Editor's Introduction

1 Introduction: Restructuring Social Work

2 The Clients of Social Work 9

Introduction 9

Who are the clients? $\quad 11$

$\begin{array}{ll}\text { Child care } & 13\end{array}$

The problem of cost $\quad 16$

Why social work intervention? $\quad 20$

The elderly and the handicapped: the nuisance of dependency

Conclusion

3 Clients and Social Democracy 32

The spirit of $1945 \quad 32$

A changed atmosphere $\quad 35$

Social democracy and social work $\quad 38$

A working-class gain? $\quad 40$

Holism and the progressive potential of social work 43

Tensions within the state $\quad 44$

$\begin{array}{ll}\text { Progressive features } & 47\end{array}$

4 Clients and the Working Class 51

Introduction 51

Strains within the working class $\quad 51$

The problem of clients 52 
Clients and stigma

Idealism and social work

Cordon sanitaire

Constructing an alternative

Where should social workers work?

Divide and rule

5 The Centrality of the Social Worker 75 Introduction $\quad 75$

The importance of the social worker $\quad 76$

The problem of contamination $\quad 79$

The COS: the origins of social work professionalism 81

The struggle for closure $\quad 83$

Professional selection: procedures and concerns $\quad 86$

$\begin{array}{ll}\text { Scientisation } & 89\end{array}$

Countervailing ideologies $\quad 92$

$\begin{array}{ll}\text { Conclusion } & 93\end{array}$

6 Social Work Education: Sustaining the Faith 95

Introduction $\quad 95$

Contamination $\quad 96$

Training or education? 101

Radicalism and politicisation $\quad 103$

$\begin{array}{ll}\text { Conclusion } & 110\end{array}$

7 Difficult Employees $\quad 112$

Introduction $\quad 112$

The Dawn House incident $\quad 120$

Forms, dossiers and the proletarianisation of social work

Computerisation

$\begin{array}{ll}\text { The struggle continues } & 131\end{array}$

8 Possibilities and Problems $\quad 135$

$\begin{array}{ll}\text { Trade unionism } & 135\end{array}$

$\begin{array}{ll}\text { Radical trade unionism } & 137\end{array}$

$\begin{array}{ll}\text { Whitleyism } & 140\end{array}$

Organising: sensitivity and imagination $\quad 144$

Considering alternatives: the coercive tilt 146 
CONTENTS

vii

Understanding capitalism

148

Social democracy in retreat

150

Immediate and medium-term strategies

152

Bibliography

158

Index

169 


\section{Acknowledgements}

Over the three years of working on this book I have benefited from the encouragement and help of many friends, and I thank them warmly for their support. My greatest debt, however, is to Tony Novak, without whose help and comradeship this book would never have been completed. He has read through countless drafts, corrected my grammar, cooked dinners and been my sternest critic and my greatest support. Finally, I would like to thank the editor of the series Peter Leonard and my publisher Steven Kennedy, both of whom have patiently offered wise comment and encouragement.

Rochdale, England

CHRIS JONES

October 1982 


\section{List of Abbreviations}

BASW British Association of Social Workers

CCETSW Central Council for Education and Training in Social Work

COS Charity Organisation Society

CQSW Certificate of Qualification in Social Work

CSS Certificate of Social Service

CTSW Council for Training in Social Work

MSC Manpower Services Commission

NALGO National Association of Local Government Officers

NAPO National Association of Probation Officers

NUPE National Union of Public Employees

SWT Social Work Today 


\section{Editor's Introduction}

The relationship between welfare 'clients', social workers and the local authority which employs them has long been considered a problematic triangular one. During the 1950s and 1960s, when psychoanalytic-based therapy seemed to be the goal of many aspiring social workers, or at least of writers about social work, almost all attention was focused on the social worker-client relationship - on emotional exchanges, on identification, on dependence, on 'problems with authority' and on transference and counter-transference within the relationship. Totally absent at this time was any serious attention, beyond a fascination with 'sub-cultural differences', to the essentially class nature of the relationship. Later, from the early 1970 s, as social services organisations grew in size and complexity and as the managerial component expanded and became more confident, social workers experienced mounting problems in their organisational roles. At the same time, increasing emphasis was given to the monitoring and control of individuals and families considered deviant or 'at risk', culminating in various moral panics, most notably in the area of 'non-accidental injury' to children.

The specific experiences of this triangular relationship by welfare clients, social workers and social services managers and local councillors, may be considered as a microcosm of a broader structural relationship: that between the working class, the occupation of social work, and the state apparatus. To consider the relationship in these latter terms is to transform immediately our understanding of it, for it provides the possibility of contextualising specific experiences in terms of their historical development and their current political and ideological significance. 
But once we step back from the immediate experiences of this relationship and attempt to understand their context, we find that many interpretations of it exist. Most significant, for our purposes, are on the one hand those who see the relationship as essentially benign, and on the other hand those who find it wholly malignant and oppressive.

There can be little doubt, of course, that the dominant view of the relationship between the state, social work and the working class is that it is essentially designed to be caring, and even where such care includes control, it operates, though they often fail to realise it, in the interests of the working class as well as of the state. This benign vision is the cornerstone of the social-democratic reformist conception of the welfare state and underpinned all the efforts during the 1970 s to 'reform the welfare' from the Seebohm Committee onwards. It was a conception of the relation between the welfare state and the working class which was especially significant to David Donnison's failed attempt, whilst Chairman of the Supplementary Benefits Commission, to use a part of the state apparatus in the interests of the poor.

More recently, it is the ideology of the Barclay Report and most especially in its proposals for 'community social work'. A basic notion in the Report is that there must be a partnership between working-class communities and local authority social services, and it is argued that despite failure in the past this partnership is still possible. As an exercise in the attempted mystification of class relations, the Barclay Report makes interesting reading. It is unlikely, however, to impress working-class communities who experience their relationship with social workers and the local welfare apparatus predominantly as control, subordination and incorporation, a relationship more likely to be characterised by antagonism than by partnership. In the 1970 s and early 1980 s, the socialdemocratic welfare consensus has come under challenge from two distinct quarters. So far as the radical Right is concerned, it sees the relationship between the state, social work and the working class as too benign, and in some respects takes a more realistic view of the strict limits to which welfare reform can be pushed without revealing basic antagonisms. 
Given the failure of welfare reformism in recent years to improve the position of the working class, it is not surprising that social-democratic prescriptions have also come under increasing challenge from a left critique which sees the relationship between the state, social workers and the working class as essentially based on oppression and control. Such an approach has the special virtue of unmasking the hypocrisy of much current discussion in the social work and social policy fields, and of revealing its underlying function, the justification of the present structure of class, gender and ethnic relations. But as the economic and social crisis deepens and is paid for by the increased oppression and suffering of the working class, it becomes increasingly urgent for the Left to develop this analysis into a coherent picture of the interaction between state welfare and the working class.

It is this task to which Chris Jones applies himself in his new book. Continuing the work of previous volumes in this series, State Social Work and the Working Class builds, through detailed empirical evidence and historical analysis, an impressive picture of the interaction between welfare clients and social workers within the state apparatus. The story which Chris Jones has to tell could in no way be characterised as primarily one of benign results for the working class, or even less of benign intentions on behalf of the state apparatus. On the other hand, Chris Jones's account shows how ambiguous and problematic for the state is the use of social workers as instruments of intervention and control in the lives of the working class. Although he differs in some important respects from two previous volumes in the series concerned specifically with social work, namely Corrigan and Leonard's Social Work Practice Under Capitalism, and Bolger, Corrigan, Docking and Frost's Towards Socialist Welfare Work, Chris Jones is essentially pursuing the same project - the careful analysis of the contradictions involved in the triangular relationship.

The contradiction central to Chris Jones's analysis is that involved in training, using and controlling a social stratum or class fraction - state employees - for the purposes of managing the working-class poor. He shows us how continuously unreliable social workers have been in this role, 
and describes to what lengths the state welfare apparatus and its training organisations have gone in attempting to ensure their loyalty. But social workers have continued to be contaminated by this contact with the working-class poor - a material experience deeply challenging to dominant ideologies. Although, as Chris Jones demonstrates, the state has been in a large measure successful in fragmenting the poor from the rest of the working class, even this strategy continues to be problematic, especially as the crisis deepens and, especially through unemployment, affects the working class as a whole.

For social workers, and others, experiencing the full impact of the control exercised over them and their work from within the state welfare apparatus, this book is most important. In particular, it shows us that to understand this control, including the subordination of social workers' judgements to the interests of welfare management, we must go beyond thinking only in terms of the effects of bureaucratic organisation, careerism and the failure of nerve in the face of moral panics, significant as these are. We must see the relationship between the state, social workers and the working class as one response to specific problems facing an advanced capitalist country in decline, namely how to control the working class and especially its poorest elements and so ensure that the balance of class forces remains safely in the interests of capital.

Chris Jones's stimulating book demonstrates again that the view of the welfare relationship as wholly oppressive is a too simple one. The contradictions and strains in that relationship provides, even in these dark days, the opportunity for social workers, these 'difficult employees', to aim for a different, more socialist, relationship with the working class.

University of Warwick

PETER LEONARD

October 1982 